\title{
The Impact of a Short-Term Study Abroad Program that Offers a Course-Based Undergraduate Research Experience and Conservation Activities
}

\section{Jacqueline McLaughlin}

The Pennsylvania State University, Lehigh V alley

\section{Mit Patel}

National Institute of Health in the Department of National Institute of Allergy and Infectious Diseases (NLAID)

\author{
D. Kent Johnson \\ Indiana University - Purdue University Fort Wayne
}

\section{Carlos L. de la Rosa}

Organization for Tropical Studies, Costa Rica

\begin{abstract}
:
Short-term study abroad experiences are the most common type of undergraduate study abroad programs offered by universities in the United States. However, and to the best of our knowledge, little empirical research exists on students' learning outcomes following their participation in a shortterm program using an integrated research praxis. To address this, we structured an international embedded program in Costa Rica and Panama which allowed students to engage in authentic research experiences topically centered in ecology and service-learning activities in conservation biology. Mixed methods analyses on data generated from the assessment of students $(n=54)$ in three cohorts, revealed students' gains (both positive and negative) in specific scientific skills and knowledge domains in both the fields of ecology and conservation biology, as well as interest in doing further field research, perceptions of authentic international field research, appreciation of the value of biodiversity, advocacy, and future actions as conservationists and informed citizens (global citizenship).
\end{abstract}

\section{Introduction}

Undergraduate research experiences (UREs) provide students with opportunities to construct knowledge by challenging them to relate concepts and scientific data to questions and issues while training them in the essential elements of the scientific process through hands-on experience (Thiry \& Laursen, 2011; Lopatto \& Tobias, 2010; Russell, Hancock, \& McCullough, 2007; Lopatto, 2004; Seymour, Hunter, Laursen \& DeAntoni, 2004; Bauer \& Bennett, 2003). Moreover, previous studies have shown that, across demographic characteristics (e.g. gender, race, ethnicity, socioeconomic status, indices of prior academic achievement), exposure to UREs have been positively associated with 
persistence to degree completion and academic success (Eagen et al., 2011; Jones, Barloe, \& Villarejo, 2010; Barlow \& Villarejo, 2004). Therefore, many prominent science-education agencies and organizations have called for more authentic research experiences in post-secondary science courses (McLaughlin \& Metz, 2016); American Association for the Advancement of Science [AAAS], Vision and Change, 2011, 2015; President's Council of Advisors on Science and Technology [PCAST], 2012; National Academy of Sciences [NAS], 2010; Project Kaleidoscope, 2002; National Research Council [NRC], 2003).

Presently, UREs generally take place outside the prescribed curriculum (Spell, Guinan, Miller, \& Beck, 2014; Harrison, Dunbar, Ratmansky, Boyd, \& Lopatto, 2011). Making research experiences more accessible to undergraduates by incorporating the practice of scientific research into classroom and laboratory curricula could thus serve to counteract the high attrition rates in science majors and foster interest in science careers for more diverse student populations (McLaughlin \& Metz, 2016; Bangera \& Brownell, 2014). One approach gaining increased momentum nationally is the course-based undergraduate research experience (CURE). Numerous studies have shown the benefits of CUREs for students: increased interest in science and research, increased self-confidence, enhanced conceptual understanding and experimental design proficiency, and improved science process skills (Brownell et al., 2015; Bascom-Slack, Arnold, \& Strobek, 2012; Brownell, Kloser, Fukami, \& Shavelson, 2012; Rhode Ward, Clark, \& Horton, 2014; Kloser, Brownell, Shavelson, \& Fukami, 2013; Shaffer et al., 2010). A recent national study has also demonstrated the benefits of CUREs to the faculty who implement them in their classrooms (Shortlidge, Bangera, \& Brownell, 2016). A CUREnet NSF report (Auchincloss et al., 2014) from a small working group of people with expertise in CURE instruction and assessment lists five essential elements of an effective CURE: (1) scientific practices are utilized; (2) the outcome of the investigation must be unknown to both the students and the instructor; (3) the work is broadly relevant or important to society; (4) group work is an essential pedagogical element; and (5) iteration must be exercised (which can occur at multiple levels). McLaughlin \& Coyle (2016) have developed a simple and flexible framework that orients and guides an instructor through the process of designing and implementing a CURE that possesses the previously mentioned five elements, which McLaughlin and colleagues (2017) (Figure 1) have implemented and evaluated. This pedagogical framework has been used to transform two sophomorelevel, introductory cell biology laboratories into CUREs at two different universities (Goudsouzian, McLaughlin, \& Slee, 2017; McLaughlin \& Coyle, 2016), an honors introductory biology laboratory for non-majors at a two-year college (Goedhart \& McLaughlin, 2016), and an introductory developmental biology laboratory for majors at a four-year college (McLaughlin \& Patel, 2017). In all laboratory paradigms, students work in small groups to learn modern biology research techniques, ask novel questions of societal value grounded in scientific literature and critical thinking, design their own experiments, and thoroughly and iteratively test their hypothesis using essential steps of the scientific method and the reflective process of progressive problem solving. They also interpret their authentic data and disseminate their work in a professional, scientific manner by means of poster presentations, oral academic talks, and publications (Figure 1). More importantly, students receive the necessary individualized mentorship that is integral to the encouragement of knowledge integration (Linn, Palmer, Baranger, Gerad, \& Stone, 2015). 
Figure 1. The pedagogical framework used to enrich UREs.

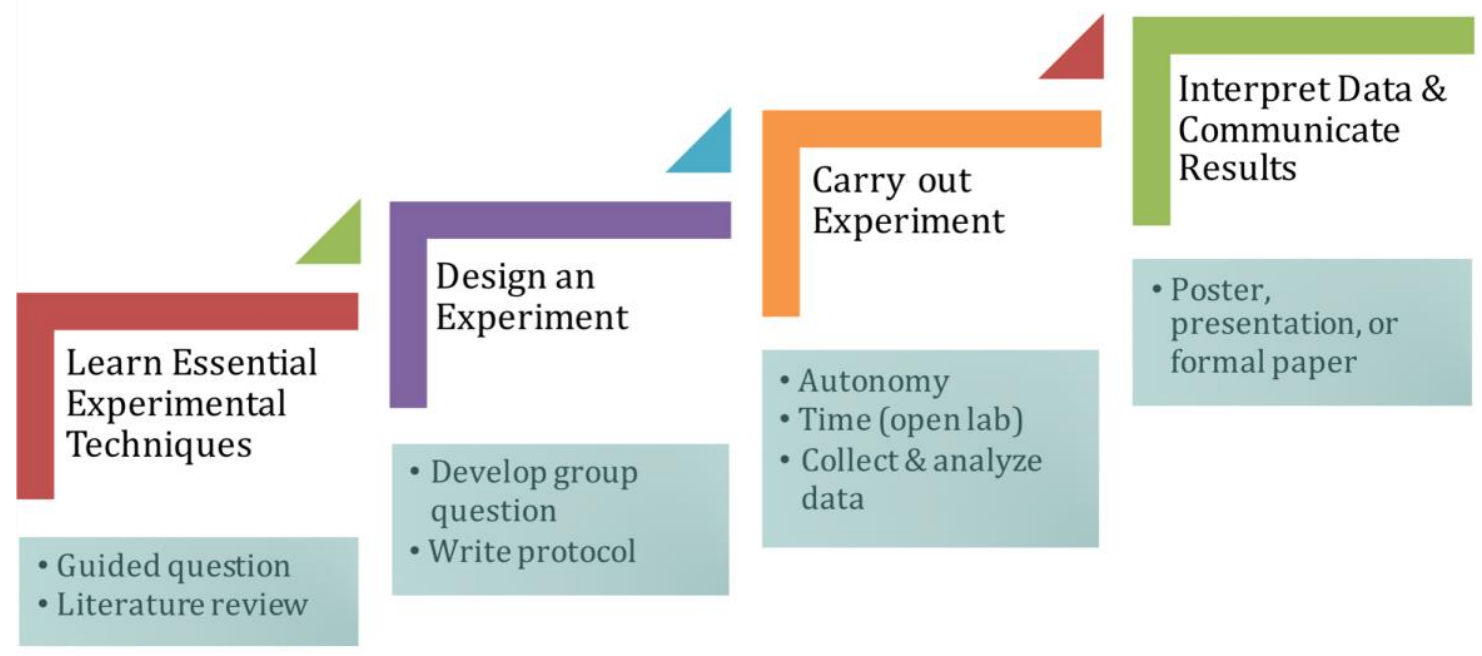

The instructor/technician(s) act as mentors for steps II-IV

Short-term study abroad experiences are the most common type of undergraduate study abroad programs in the United States (Institute of International Education [IIE], 2013). Indeed, 60\% of study abroad experiences are one to eight weeks in duration, a percentage that has grown substantially over several decades (IIE, 2015). These programs vary from week-long programs conducted during spring break to two- to four-week programs conducted during January winter break or the summer, to longer programs of up to eight weeks or a semester. They can involve homestays, travel to multiple sites, service learning, and/or undergraduate research experiences. They can also be "embedded" into the framework of a semester-long course. The key to understanding academic short-term study abroad is the sheer diversity of available programs, supported by the research of Donelly-Smith (2009), who states "there is no 'average' short-term study abroad program; the variations are as numerous as the institutions that host them."

In this study, we assessed the perceived learning gains of three cohorts of students who partook in a unique short-term study abroad program in Costa Rica and Panama. Explicitly stated, this program provided students with the opportunity to conduct research in the form of a CURE in the field of ecology - the scientific analysis and study of interactions among organisms and their environment. The CURE was designed according to the aforementioned four-step framework used in traditional undergraduate laboratories. Students also partook in numerous service-learning activities centered on conservation biology - the study of the phenomena that affect the maintenance, loss, and restoration of biological diversity in select environments. The overarching goal of this composite program is to create an immersive experience wherein students not only learn about ecology by doing research but also come to understand the broader discipline of conservation biology through handson conservation restoration efforts. The latter is of utmost importance since in today's world, the biosphere and many of its life forms face multiple threats (Dinerstein et al., 2017; Joppa et al., 2016; Titeux, Henle, Mihoub, \& Brotons, 2016a; Titeux et al., 2016b; de la Rosa, 2014; Thomas et al., 2004). Furthermore, there is no argument against the statement that the diversity of life on Earth is essential 
for human destiny and global sustainability, and that this information must be conveyed in an educationally sound and effective way to our youth.

We hypothesized that students would benefit in scientific skills and knowledge in the field of ecology following participation in the field-based CURE, and that their cumulative field research and conservation-oriented service activities would further enrich these outcomes in the fields of both ecology and conservation biology. Explicitly based in empirically supported pedagogical praxis, we also reasoned that involvement in this unique short-term program would provide a critical platform to foster global citizenship at the undergraduate level (Stoner et al., 2014).

\section{Instructional Design}

Penn State University's Connecting Humans and Nature through Conservation Experiences (CHANCE) is an accredited, international environmental education program, whose overarching goal is to teach conservation biology and global sustainability at the front line. To do this, CHANCE creates unique learning environments such as international field courses and online research modules that immerse students and/or teachers in "real-world" research and conservation efforts.

Each CHANCE field program strictly employs the "Field Course Experiential Learning Model" (Zervanos \& McLaughlin, 2003), which evolved from repeated short-term study abroad field course experiences in selected biomes around the world over a six-year period. Assessment of student learning guided the development of the integrated three-part model: pre-trip assignments (preparation), a field-based practicum (experience), and post-trip assignments (reflection) that encourage the integration and application of what has been learned (McLaughlin \& Johnson, 2006). Each CHANCE short-term study abroad program consists of two courses taken sequentially as a unit. The first course is an online biology course taken during the late spring semester. The second course is a field research trip (practicum) that provides real-world research and conservation experiences. Since 2008, the CHANCE program has integrated authentic research in its field-based pedagogy.

Online Ecology Course - Conservation Biology and Sustainability of Select Tropical Ecosystems. During the second half of the spring 2014, 2015, and 2016 semesters, students engaged in online lessons designed to develop their pre-field trip knowledge in the following content areas: 1) the biodiversity and conservation issues of the ecosystems to be explored; 2) science and research data supporting global climate change; 3) published scientific literature on specific ecological research projects to be undertaken in the field; 4) the natural history and plight of sea turtle populations worldwide; 5) conservation and scientific work of two non-governmental organizations (NGOs), Organization of Tropical Studies La Selva Biological Station (OTS/La Selva) and Asociación de Amigos y Vecinos de la Costa y la Naturaleza (AAMVECONA); and 6) the geography, culture, government, educational and environmental policies, and indigenous people of Costa Rica and Panama.

Field Course - A Field Practicum in Costa Rica and Panama. The 17-day long summer field practicum provided seven days of field-based research experience mentored by scientists associated with OTS/La Selva. The field research focused on tropical rainforest ecosystem ecology and biodiversity. Students, working in groups of four to five, conducted an authentic research project using 
the four-step pedagogical framework (McLaughlin \& Coyle, 2016). Students' projects covered topics such as the biodiversity of tropical Chironomidae (non-biting midges, Diptera) and their use in water quality bioassays; Atta cephalotes (leaf-cutter ants) ecosystem engineering and shifts in microclimates; foraging behavior and spatial memory in Phaethornis longirostris (long-billed hermit); faunal assessment of bromeliad microcosms in the disturbed rainforest of OTS/La Selva; and, the function of stilt roots in the growth strategy of Socratea exorrbiz, (walking palm). Student groups presented their research findings in an oral format to the OTS/La Selva scientific community at a symposium. The field practicum also provided seven days of service-learning activities wherein students volunteered at select sea turtle conservation sites in both Costa Rica and Panama run by AAMVECONA. Groupbased service-learning activities included 24-hour protection of relocated sea turtle nests from poachers via shift work; beach night patrols to search for nesting females whom if encountered were tagged, analyzed for health issues, and measured for body dimensions, while eggs were collected and moved to a protected hatchery; daily beach cleanup to remove trash and logs; and planting native trees as part of reforestation efforts in select farmlands. Remaining days consisted of traveling between destinations and field guided excursions to National Parks, forests/mangroves, and historic sites; biodiversity lectures by expert field guides and faculty; and cultural experiences. Throughout the 17day field practicum, instructors supervised daily, guided journaling and reflection activities, and oversaw all field components including the implementation of the four-step pedagogical framework.

Three CHANCE field programs were implemented over a three-year period in Costa Rica and Panama, all of which were identical in course design and itinerary. All participants were undergraduate students from varied backgrounds and majors including several pre-service instructors. It was required that all students complete the identical pre-trip and post-trip online assignments. However, students enrolled in the higher 400 level courses were required to complete additional online assignments and lead the organization of their group's field presentation efforts.

\section{Assessment Methods}

All research conducted for this study is protected by the Pennsylvania State University Internal Review Board, which graciously approved this study (IRB\# 41481). The assessment design utilized a mixed-methods approach in which quantitative and qualitative data were gathered from students $(n=54)$ across three consecutive years. Modified versions of the short-term study abroad assessment instruments developed by McLaughlin \& Johnson (2006): field research survey, post-trip survey, and post-trip reflective assignment were administered. The field research survey consisted of both closedended and open-ended questions related to students' perceptions of gains in specific scientific skills and knowledge, as well as issues related to field research. This survey was administered immediately following student participation in the CURE-based field experience at OTS/La Selva. The post-trip survey was administered on the last day of the field program and consisted of closed-ended response questions related to students' perceptions of gains in general scientific skills and knowledge. The posttrip reflective assignment was administered one month following the return from abroad in order to allow students additional time to reflect on their experiences from the entire program. It consisted of open-ended questions that allowed students to share their insights and feelings on how the composite program influenced their broader understanding of conservation biology and conservation-based practices.

Quantitative: Survey Development and Analysis. The field research survey addressed 
students' perceptions of 14 Inquiry and Science Education Standards set forth by the National Research Council [NRC] as benchmarks for undergraduate research excellence (2000) (Figure 2). The survey asked students to rate their interest in doing further field research and their understanding of conservation biology and global sustainability. The post-trip survey allowed students to rate their perceived abilities to perform additional scientific skills and their understanding of specific knowledge domains in the fields of both ecology and conservation biology. Student responses in both field and post-trip surveys were rated on a Likert scale ranging from one to five, where one was "none" and five was "very significant." Additionally, pre-and post-trip evaluation surveys were administered to the year-3 cohort to evaluate differences in students' gains in identifiable skills and knowledge areas following the participation in this short-term study abroad program. The paired pre- and post-trip responses were analyzed as nonparametric ordinal data.

Qualitative: Survey Development and Analysis. Students responded to four open-ended questions from the field research survey to evaluate and comment on their field research experience: (1) What additional skills (other than the NRC skills listed) do you believe you have gained from your research experiences at OTS/La Selva?; (2) How have your field research experiences at OTS/La Selva changed your perspective of scientific research in general?; (3) How have your field research experiences at OTS/La Selva changed your perspective on the importance of research as it relates to climate change and loss of biodiversity?; (4) How does the field research you performed in OTS/La Selva compare to previous research you have done as an undergraduate? Additionally, two open-ended questions defined the post-trip reflective assignment: What was the most significant thing that you learned about conservation in general throughout this experience? and, in your opinion, what is the value in sustaining our world's diverse ecosystems? Two independent evaluators collectively coded student responses to these questions.

The four open-ended questions from the field research survey and two additional questions from the post-trip reflective assignment provided the data for the qualitative analysis. The initial analysis of responses to the open-ended questions followed a framework commonly used in the grounded theory tradition as described by Creswell (1997).

- The researchers performed an open coding of the data (student responses to open-ended questions) to form initial categories of information about student experiences and their descriptions of learning gains.

- The researchers then carried out an axial coding exercise in which the data were assembled to identify, clarify, and categorize broad themes from the student responses across the questions.

- From this information, the researchers developed "storylines" through a process of selective coding to organize the student responses within and across questions (Creswell, 1997). These themes provided a foundation for looking at the student responses in the context of a case (Marriam, 1988).

The experiences prior to the study abroad program, the experiences in the field, and the reflection of the experiences upon completion of the program provided the boundaries for the case. Student reflections summarizing their experiences formed the data set. The coding and analysis procedure of the data was conducted as a single program (within-site) study with the student reflections 
summarizing their understandings across multiple experiences. A thematic analysis of the survey categories and student interpretations of their involvements that cross categories formed the basis for interpreting the meaning of the field study experiences (Lincoln \& Guba, 1985). Consistent with Lincoln and Guba (1985), specific themes were collected and multiple references to a single theme by a single student were combined within the categorical count to prevent "double-counting."

Figure 2. The percentage of students' responses to 12 NRC skills and two knowledge benchmarks (bolded) following their participation in the field-based CURE. The student ratings are reported on a Likert scale of five categories: none, minimal, moderate, significant and very significant, centered at moderate. $(\mathrm{n}=54)$

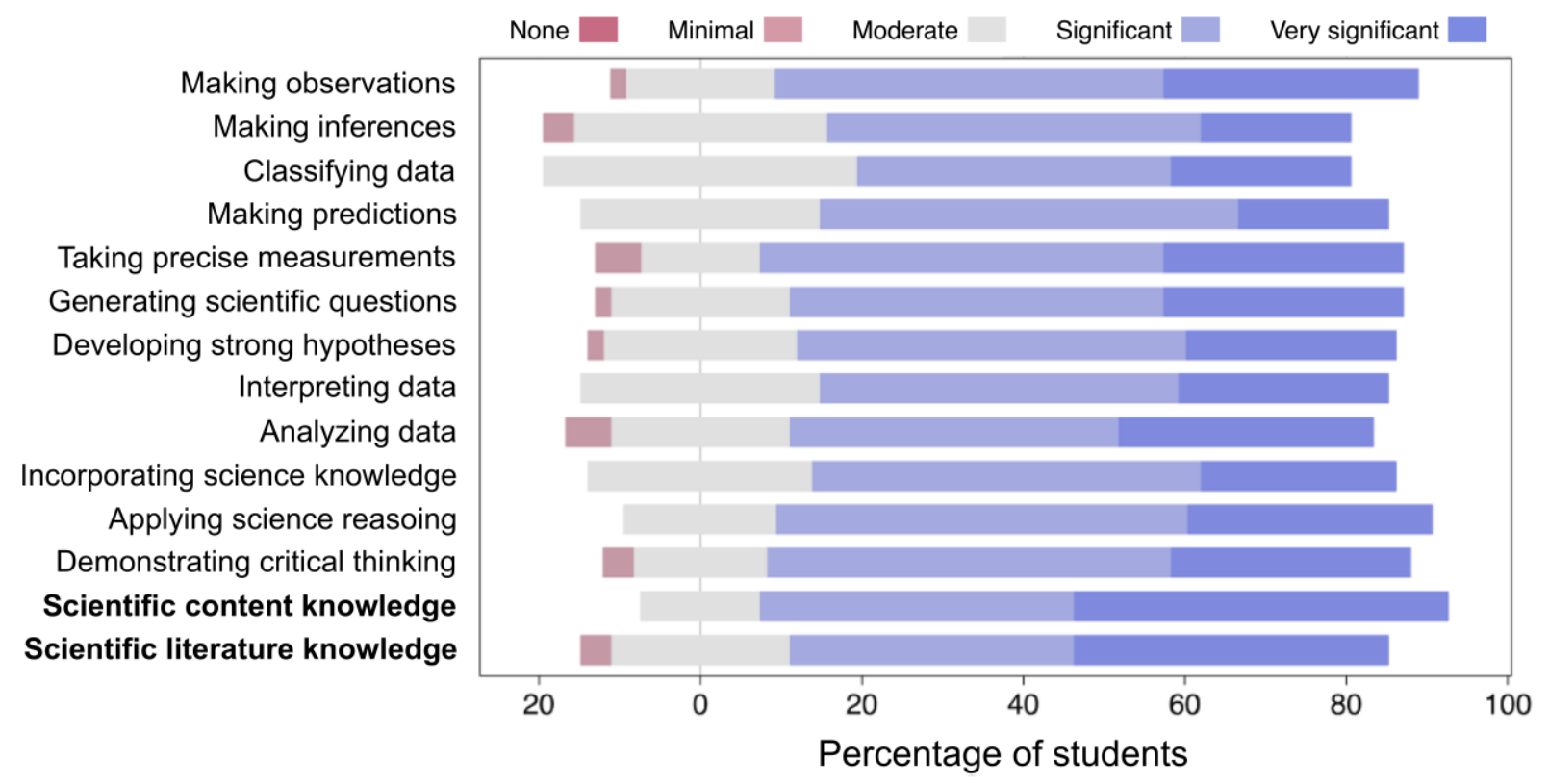

\section{Quantitative Results}

Following their participation in a CURE-based field research project mentored by professional field scientists, 54 students rated themselves in the $12 \mathrm{NRC}$ scientific inquiry skills and two knowledge levels (knowledge in specific scientific area investigated and knowledge in research literature related to scientific area investigated). For each of these benchmarks, at least $80 \%$ of students identified on the significant or very significant side of the Likert scale spectrum, centered on the percentage of students reported to have gained moderate skills and knowledge (Figure 2). A higher percentage of students perceived that they had either significant or very significant levels of skills in making observations, generating scientific questions, taking precise measurements, applying science reasoning, and demonstrating critical thinking. On the other hand, about one-third of students felt they had minimal to moderate amount of skills in classifying data and making inferences from the data. After engaging in the CURE, students perceived themselves as having more confidence in scientific content knowledge compared to scientific literature knowledge in their related field research project. Additionally, the majority of students reported significant or very significant interest in doing further research in the field (Figure 3). All of the students reported having a better understanding of conservation biology and global sustainability. 
Figure 3. The percentage of students' responses to their interest in doing further research in the field, and gains in their understanding of conservation biology and global sustainability after engaging in the field-based CURE. The student ratings are reported on a Likert scale of five categories: none, minimal, moderate, significant and very significant, centered at moderate. $(\mathrm{n}=54)$

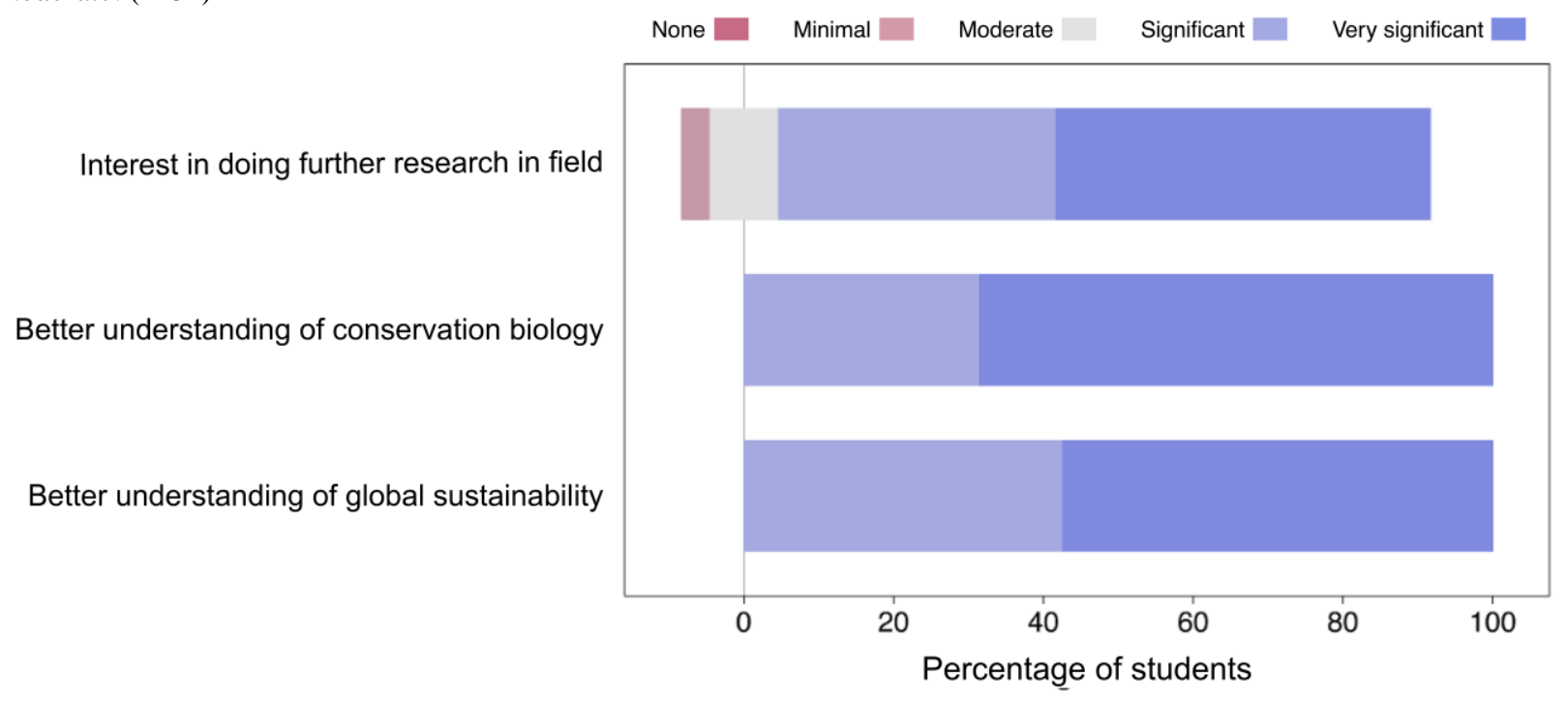

At the culmination of the short-term study abroad program, more than $90 \%$ of students expressed significant to very significant levels of skills in their ability to effectively present information to others, conduct field research, and work in a team to enhance learning (Figure 4A). In contrast, students perceived communication through writing as their weakest skill in all of the basic science skills. A majority of the students reported having a moderate, significant or very significant amount of knowledge in specific knowledge domains related to conservation biology - the importance of environmental education, how human activities impact biodiversity and the ecosystem, and global climate change and species extinction (Figure 4B). However, only about two-thirds of the students felt they had gained either a significant or very significant amount of understanding of ecosystem dynamics and stability (Figure 4B).

Figure 4. The percentage of students' responses to gains in a) different scientific research skills and b) specific knowledge domains in ecology and conservation. The student ratings are reported on a Likert scale of five categories: none, minimal, moderate, significant and very significant, centered at moderate. $(\mathrm{n}=54, * \mathrm{n}=53)$

A)

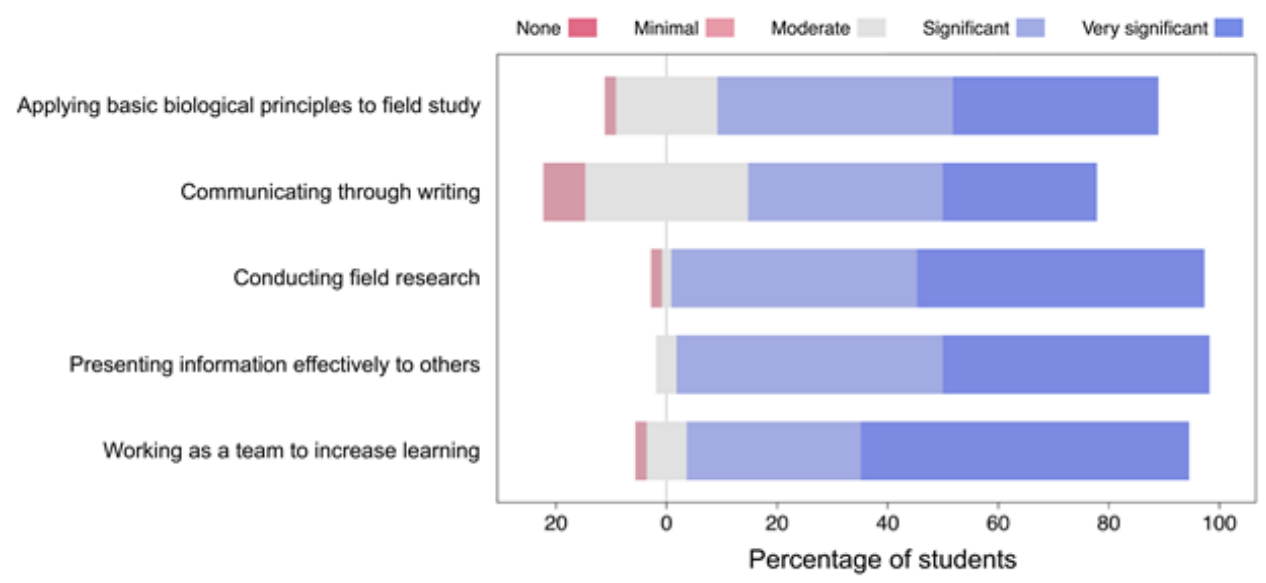


B)

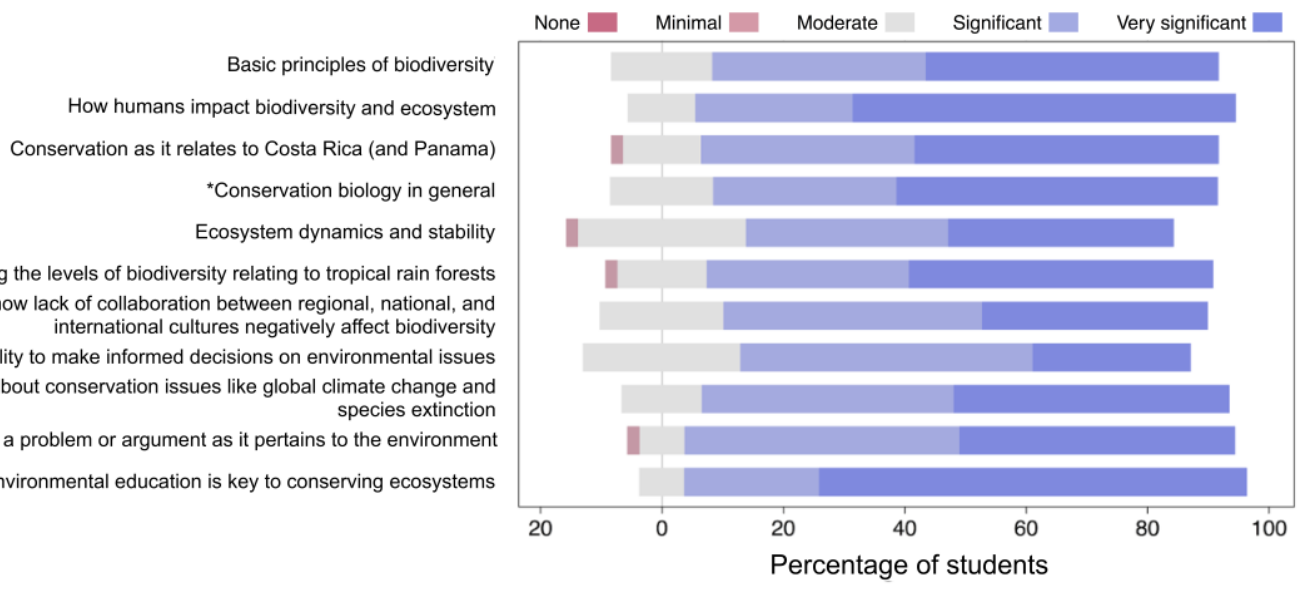

Figure 5. Sum scores of students from year-3 cohort in a) skills and b) knowledge domain questions before (pre) and after (post) participating in the field practicum. The students' scores of five skills domain questions and the scores of 11 knowledge domain questions were summed together. The matched pairs sum scores before and after participating in the program were analyzed with two-tailed Wilcoxon signed-rank test. Students reported higher gains in both skills and knowledge post-trip experience in comparison to the control (pre-trip). The central horizontal line represents the mean of the sum scores of skills and knowledge measured on a Likert scale equivalent to one to five. Error bars represent SD of mean. $(\mathrm{n}=21, * * * * \mathrm{p} \leq 0.001)$

A)

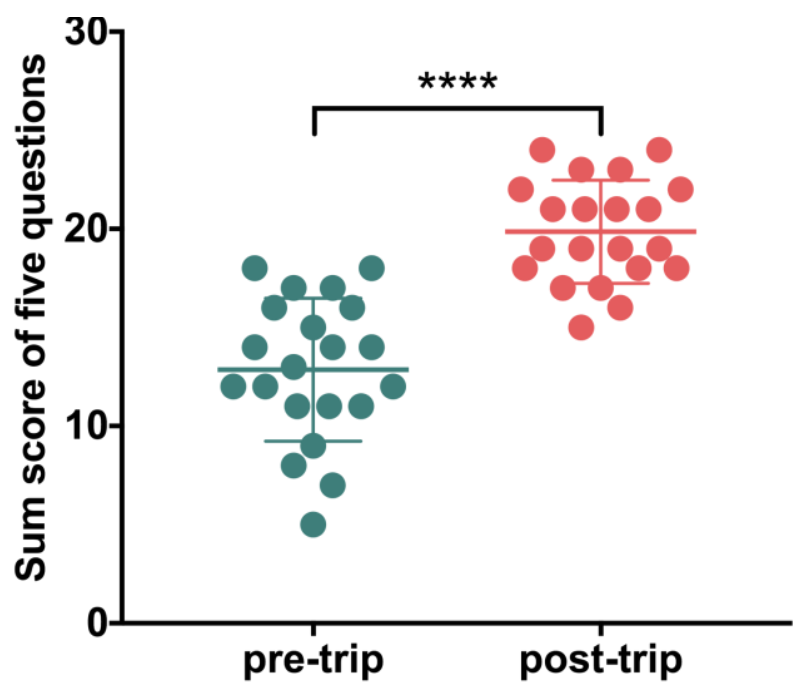

B)

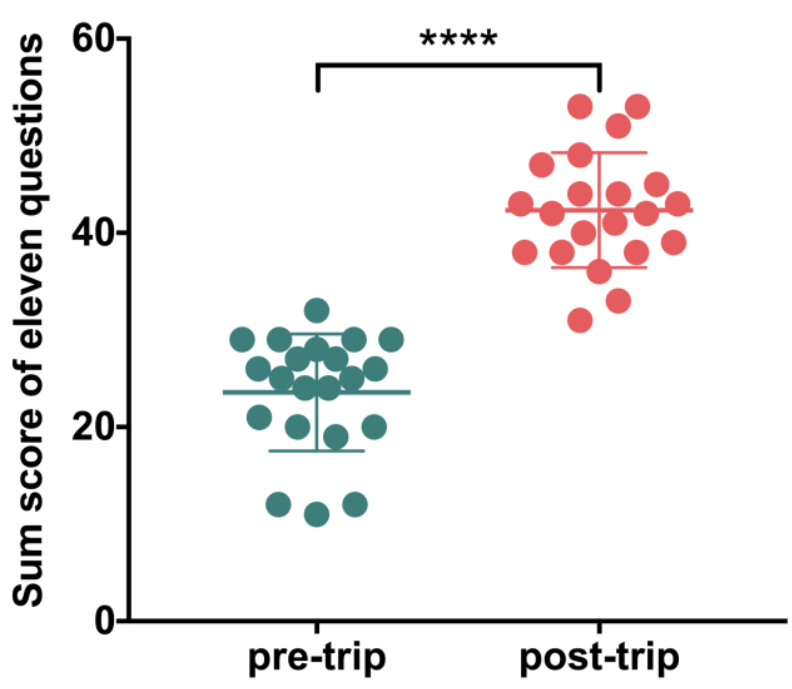

Finally, there were significant differences between students' rating of scientific skills and their understanding of specific knowledge from pre- and post-trip surveys administered to the year-3 cohort. The score from five questions related to scientific skills (Figure 4A) and the 11 questions related to ecology and conservation biology knowledge (Figure 4B) were summed and analyzed as matched pairs. A two-tailed Wilcoxon signed-rank test revealed that there was a very significant increase in skills perception scores of students' post-survey responses in comparison to the pre-survey responses (Figure 5A, W(20) $=-190, \mathrm{p}=.0001)$. Likewise, there was also a very significant increase in knowledge perception scores of students' post-survey responses in comparison to the pre-survey responses (Figure 5B, W $(20)=-231, \mathrm{p}=.0001$ ). These results suggested a positive impact on students' perceptions of basic science skills and specific knowledge domains in the field of ecology and 
conservation biology following their participation in this unique study abroad program incorporating both CURE and conservation service-learning activities.

\section{Qualitative Results}

Open-ended student responses were obtained from both the field research survey that assessed the CURE at OTS/La Selva and the post-trip reflective assignment that assessed the composite field research and conservation experience. Collected themes were categorized as either "research" or "conservation" oriented (Table 1 and 2).

\section{Research}

Students perceived the most significant gains in their ability to perform experimental field research and research methods, understand the challenges associated with field research, and grasp the importance of research as a means to address environmental challenges (Table 1).

Table 1. Student reported themes related to field research in ecology

\begin{tabular}{llll}
\hline \multirow{2}{*}{ Themes } & \multicolumn{2}{l}{ Percentage Reported } & \\
& $\mathbf{y r - 1}(\mathbf{n}=\mathbf{1 7})$ & $\mathbf{y r - 2}(\mathbf{n = 1 6})$ & $\mathbf{y r - 3}(\mathbf{n = 2 1})$ \\
\hline Ability to perform field research and research methods & 65 & 88 & 81 \\
$\begin{array}{l}\text { Understanding challenges specific to field research } \\
\begin{array}{l}\text { Understanding the importance of field research as a } \\
\text { means to address environmental challenges }\end{array}\end{array}$ & 47 & 81 & 52 \\
\hline
\end{tabular}

Ability to perform field research and research methods (78\%)

Multiple students illustrated how learning gains occurred regardless of their prior research experience. One student wrote, "At first I didn't really know how one would go about performing research. But now I learned the basic process and what is needed in order to have a good research topic ...." Students' newfound abilities to "do" field research were also complemented by gains in confidence, as exemplified by this student: "It has given me confidence in myself to conduct meaningful field research, and present that information to peers." An important aspect of the development of research skills is the application of critical thinking in the research process. One such example noted: "This experience has taught me to consider many other factors that need to be considered in scientific investigations."

Understanding challenges specific to field research (59\%)

Students also gained an understanding of the challenges of conducting research in the field. A student acknowledged, "Now I understand how hard and complex scientific research in the field is and how important it is to be very attentive and pay attention to the smallest details." While another student wrote, "They have shown me the less glamorous side of research such as the tedious data collection." Students also recognized challenges related to the variability and the complexity of scientific research. "Doing research in the field can sometimes be unpredictable. The cookie-cutter idea of the scientific method does not always apply. Science is an iterative process that is constantly revised." 
Understanding the importance of field research (81\%)

Students often expressed their appreciation for the importance of field research in addressing environmental challenges. In an open-ended response, one student wrote, "My investigation opened my eyes to the real-world problem of climate change...." An example of a transformative statement is, "My research experiences at La Selva have educated me about the realities of climate change and loss of biodiversity. Through this experience, I have become very passionate about research and how it relates to conservation."

\section{Conservation}

For the area of conservation, students described how varied ecosystems function to provide environmental services, acknowledged their responsibility to engage in conservation activities, stated intentions to advocate for conservation, and described complex relationships between human activities, climate change, and biodiversity (Table 2).

Table 2. Student-reported themes related to conservation biology

\begin{tabular}{llll}
\hline Themes & \multicolumn{2}{l}{ Percentage reported } & yr-3 (n=21) \\
\hline Understanding the function and value of ecosystems & 82 & 75 & 67 \\
Responsibility to engage in conservation activities & 88 & 88 & 67 \\
$\begin{array}{l}\text { Intention to advocate for conservation } \\
\begin{array}{l}\text { Understanding relationships between human activities, } \\
\text { climate change, and/or biodiversity }\end{array}\end{array}$ & 82 & 81 & 57 \\
\end{tabular}

Understanding the function of ecosystems (74\%)

Student responses demonstrated an in-depth understanding of ecosystem(s) structure and value. One student described contributions of multiple ecosystems, "Every ecosystem provides a unique benefit. Mountains concentrate fresh water, wetlands filter water, coral reefs provide protection for hundreds of creatures, and forests provide clean air." Many students consistently stated their understanding of the unique benefits of ecosystems, often together with the importance of biodiversity. A student wrote, "There is great value in sustaining biodiversity globally; one such reason is for protection of ecosystem services they provide. For example, the mangroves substantially protect the inland areas from water damage as a result of flooding and otherwise harmful water patterns. Seagrasses also provide a type of bio-filtration system that purifies and detoxifies the water that runs through it."

Responsibility to engage in conservation activities (79\%)

Students' understanding of ecosystems extended to a sense of responsibility to engage in conservation activities. A student expressed that "the most significant thing that I've learned about conservation in general throughout my experience in Costa Rica and Panama is that we must start taking action now to repair broken ecosystems." Multiple students described the importance of even 
small-scale conservation activities. "I think that the most significant thing I learned about conservation is that no matter how small the effort is, it will still go a long way in helping the overall effort for conserving our planet." Students perceived the responsibility for conservation work as personal and urgent. "I learned that I can't hope that someone else will do it. I have to be the one to get out there and do it."

Some examples of specific plans for action included: “...using less water and plastic, and more recycling," and "I hope to be a college professor one day and if I achieve my goal, I will most certainly teach my students how important sustainability is, and maybe I'll even be able to run an environmental program."

Intention to advocate for conservation (67\%)

A majority of participants made statements about the extension of the responsibility to engage in conservation to the point of advocacy. One student described, "I had always thought that people were the enemy in conservation work, and we (conservationists) needed to save the environment. Thinking like this does not accomplish anything; we must work with the public and people of all lifestyles to aid in their education about conservation." Another student stated that "the most significant thing I learned about conservation during my experience was the importance of communication and public relations... we must work with the public and people of all lifestyles to teach them about the importance of conservation." Another wrote, “...since everyone cannot go to CHANCE, it is important for those of us lucky enough to go on to teach our family, friends, and future children its importance." Moreover, a final example was, "the more people are educated in conservation and sustainability, the better our future looks for the world around us. It is my job to educate."

\section{Comprehending complex relationships (85\%)}

The cumulative experiences of students in environmental research and conservation work had a profound impact on their grasp of complex relationships between human activities, biodiversity, and/or climate change. Students frequently described the "interconnectedness" of these relationships. "To me, the overwhelming theme of the trip was interconnectedness; biodiversity is a web, some aspects with obvious ties and others, more delicate, that require more work to see and understand." Another student related the value of sustaining the environment to potential impacts on the quality of human life. "In the rainforest alone, there could be countless medicines that we have yet to find and derive from the plants and fungus. We could literally rid the world of countless diseases and ailments...." And, another noted, "A diverse ecosystem means a more diverse biodiversity, and biodiversity boosts ecosystem productivity. Each species, no matter how big or how small, has an important role (niche) to play. As such, everything depends on something else. Thus, we humans depend on a world with diverse ecosystems." An example of students' enhanced grasp of complex relationships was, "Diverse ecosystems provide genetic diversity which is critical for the survival of life on Earth. Without genetic diversity, a single event could wipe out most or all life. Also, different ecosystems provide different 'services' for the Earth, such as carbon uptake in the rainforests."

\section{Discussion}

In this study, we reported students' perceptions of scientific skills and knowledge in the field of ecology and conservation biology following a unique short-term study abroad program that offered a 
CURE and conservation-based activities in Costa Rica and Panama. Students reported significant to very significant gains in NRC scientific skills and knowledge benchmarks following their CURE in OTS/La Selva. Additionally, they showed higher interest in doing further research in the field of ecology and conservation biology, and their understanding of conservation biology and global sustainability improved after engaging in the CURE. In the survey administered at the end of the study abroad program, students reported significant to very significant gains in other scientific skills as well as specific knowledge domains in ecology and conservation biology. Additionally, year-3 students reported a significant increase in their perception of essential scientific skills and specific knowledge domains in ecology and conservation biology in the survey administered before and after participating in the study abroad program. These collective results suggest the students' participation in this program, which offers both field research and conservation service-oriented activities, enhances their scientific skills and furthers their understanding of ecology and conservation biology.

The results also shed light on the benefits of this unique experiential and immersive short-term program on students' personal growth into environmental advocates and informed citizens eager to take personal action and change their lifestyles. Global citizens or "globally minded citizens" understand the interdependency of the world and its inhabitants, and the connective links that exist between all living things (Backhouse, 2005). It is generally accepted that global citizenship includes three key dimensions: social responsibility (a concern for humanity and the environment), global awareness (alertness and responsiveness to issues that are global in nature), and civic engagement (active, informed participation in local, national, and global affairs) (Morais \& Ogden, 2011; Tarrant et al., 2011; Schattle, 2009). It is apparent that the students that partook in this short-term international program grasped these three dimensions of global citizenship. The majority shared a meritorious viewpoint that reflects their global sense of belonging to an interconnected living planet, a responsibility to protect and sustain biodiversity, and a heartfelt desire to alleviate the degradation of nature in their lifetimes.

The CURE aspect of this program is ambitious in its goals, packing a lot of information and experiences in a concise period of field work. Indeed, the four-step pedagogical framework which usually spans eight weeks in a traditional "open" biology lab was adapted and executed over an intense seven-day period used in this study (McLaughlin \& Coyle, 2016). While students showed significant gains in the majority of skills surveyed, relatively low scores were identified in the acquisition of skills in classifying data and making inferences from the data. This can be improved by (1) increasing the data analysis and data interpretation in online pre-trip activities, or (2) increasing the time in the field spent in the area of the experience. Since the student research projects are part of larger research programs of the researchers themselves, this would require establishing a longer relationship with the researchers during the course, where the students can acquire understanding and knowledge prior to the field experiences beyond reading the scientific papers provided by the researchers.

Another shortcoming of the program revolved around students' perception of knowledge and conceptual understanding gained in the more advanced and broader area of rainforest ecosystem dynamics and stability. This may have stemmed from the very detailed nature of the researchers' projects that the students were involved in because they were often observing specific and microscopic elements of a macroscopic question. Most of the time with the researchers was spent learning basic concepts and techniques, characterizing organisms into a general category (e.g., family level in aquatic 
insects, or one species of bird among many), and developing sufficient proficiency to collect viable and efficacious data for analyses. Less time in the field was dedicated to discussions with the researchers on the "bigger picture" and intricacies of their research.

One way to improvise would be adding a daylong session with all the researchers and students where the "broader impacts" of their research are discussed. This is standard in many research proposals (such as those to the National Science Foundation [NSF]) and is extremely important to put a research topic into a broader societal or scientific context. Another way to remedy this issue would be increasing the duration of the overall CURE in the field. Nonetheless, this finding is in alignment with research that suggests that students need guidance to understand the rationale, research design, and contribution to the field in a new area (Thiry, Weston, Laursen, \& Hunter, 2012; Thiry \& Laursen, 2011).

There are subtle, but essential elements of this composite program that relate to the field learning experience that must be recognized: (1) The research experiences were authentic. All associated scientists integrated the students and the data they collected into their research projects. This brought relevance and immediacy to the students' experiences with the research. (2) The day-to-day discussions in the field and laboratory were informal, unscripted, and genuine. As such, students had additional "first-hand" learning experiences in how researchers solve problems (e.g., how to repair field equipment, collect data, and select field sites in a jungle), and respond to the uncertain and often dynamic nature of research (such as weather in the field or "lack of collaboration" from the study subjects). These are topics that are very difficult to replicate or plan for in a classroom setting; and (3) The students participated in ongoing conservation activities by working alongside local conservationists. The unstructured conversations, sharing of travails, direct observation, and experience of the severe conditions under which tropical conservation work is carried out, made these experiences deeply impactful and meaningful for the students. Additionally, and importantly, the fieldbased research and conservation experiences were framed within a robust pre-trip design and a posttrip reflection that made these experiences a consequential milestone in the development of the student's critical thinking and desire to learn.

Previous studies have shown an increase in students' scientific knowledge when performing scientific tasks in the field because of the interactions of affective, psychomotor, and cognitive activities required in such a setting (Dresner, de Rivera, Fuccillo, \& Chang, 2013; Scott et al., 2012). Moreover, student achievement of higher order cognitive levels was further enhanced by sequential curricular experiences in which students were introduced to biodiversity and environmental science concepts in the classroom, followed by a second course experience where students participated in a field-based CURE (Dresner, de Rivera, Fuccillo, \& Chang, 2013). This pattern of course-based experiences followed by a field-based experience is consistent with the field-based experiential model that formed the foundation for the student experiences in this study abroad program (McLaughlin \& Johnson, 2006; Zervanos \& Mclaughlin, 2003).

Field work is an essential component of an undergraduate education in the environmental sciences. Importantly, many research scientists have been implementing short-term study abroad experiences in global biological field stations around the world that involve undergraduate research for decades. Our study highlights the scholarly benefits of CURE instruction using a four-step 
pedagogical framework as an essential component of a unique short-term study abroad program. Additionally, our study revealed that even short-but intense-combined field research and conservation experiences can leave strong and lasting impressions on student's opinions of conservation, and their growth into informed decision makers on matters that relate to environmental issues local and abroad, advocacy, future careers, and personal behaviors. Numerous studies on connections between affective learning and student transformation, or the now revised transformative learning theory which includes neurobiological perspectives, support this interpretation (Taylor, 2001; Mezirow, 2000).

Our research provides the first evidence that when a CURE is utilized in a non-traditional, shortterm study abroad learning environment, student outcomes are enhanced. To the best of our knowledge, there are no validated assessment tools to evaluate CUREs in an embedded study abroad program. Several validated instruments do exist, but only to assess the affective and established outcomes of traditional laboratory-based CUREs (Dasgupta, Anderson, \& Pelaez, 2014; Deane, Nomme, Jeffery, Pollock \& Birol, 2014; Brownell et al., 2013; Gormally, Brickman, \& Lutz, 2012; Sirum \& Humberg, 2011). As the field of biological sciences education gains momentum then, it is necessary that we begin to move forward to assess these non-traditional study abroad environments in a way that measures both the conceptual side of learning and the development of students' 'soft skills,' e.g. presentation skills and writing abilities (Boyce, Williams, Kelly, \& Yee, 2001). Presently, we are using a nationally validated modified rubric that acts as a form of summative assessment. This rubric scores students' presentations on four constructs in order to measure their hard and soft skills resulting from their participation in a CHANCE CURE. This shift in pedagogical research methods coincides with the ever-changing, improving, and iterative nature of assessment in biology education (Linn et al., 2015; Lopatto, 2017).

In closing, it is essential to highlight recently published research which strongly argues that semester-long study abroad programs provide a broader array of positive learning outcomes as compared to short-term study abroad programs because they offer more 'time' for students to be immersed in experiential learning (Coker et al., 2018). We negate this generalization and remind all those working in the field of international programs, that both short-term or semester-long programs, either compared within their own group or between groups, vary in characteristics like shoes in a closet. When making comparisons between any group (program), we must look more closely as to what activities, critical reflection, and assimilation opportunities that maximize the efficiency and productivity of student learning are offered (Co-Constructed Developmental Teaching Theory (CDTT) (Schenck \& Cruickshank, 2015). Our study shows that when a structured CURE (practical research value) and conservation activities were integrated into a short-term study abroad program using the field-course experiential learning model (McLaughlin \& Johnson, 2006), significant affective and conceptual outcomes are achieved. Importantly, other outcome-based research has also shown that well-structured study abroad programs, of any duration, have the potential to create an extraordinary learning opportunity for students (Chieffo \& Griffiths, 2004; McKeown, 2009; McLaughlin \& Johnson, 2006; National Survey of Student Engagement, 2007; Tarrant \& Lyons, 2012).

Future research on the impacts of short-term study abroad programs which provide defined and high caliber curricular goals and structured experiential-learning activities on student 
outcomes is critical. The findings of such studies will improve institutional direction and the reputation of those short-term programs with proven depth and value as being more than just a 'trip.'

\section{Acknowledgments}

First, we want to thank all of the researchers that participated in the CURE programs in Costa Rica, including Drs. Diego Dierick, Marcelo Araya, Paul Foster, and Socorro Ávila and Ronald Vargas, as well as the staff of the OTS/La Selva for their administrative, laboratory, field, and logistic support. Second, we want to thank all the conservationists, especially Erick Gabarrete from AAMVECONA, for their willingness to participate in this program and to share their passion and dedication to conservation. Thirdly, we are grateful to Heather Amatore for her expert editorial services, and Dr. Susan Singer for her invaluable input. Lastly, we are indebted to David Esparza for his important input on pedagogical assessment.

\section{References}

[AAAS] American Association for the Advancement of Science. (2011). Vision and change in undergraduate biology education: A call to action. Washington, DC.

[AAAS] American Association for the Advancement of Science. (2015). Vision and change in undergraduate biology education: Chronicling change, inspiring the future. Washington, DC.

Auchincloss, L.C., Laursen, S.L., Branchaw, J.L., Eagan, K., Graham, M., Hanauer, D.I., ․ Dolan EL. (2014). Assessment of course-based undergraduate research experiences: A meeting report. CBE - Life Sciences Education,13(1), 29-40.

Backhouse, F. (2005). Invite the world into your classroom. University Affairs, 21 - 25.

Bangera, G. \& Brownell, S. E. (2014). Course-based undergraduate research experiences can make scientific research more inclusive. CBE-Life Sciences Education, 13(4), 602-606.

Barlow, A. E. \& Villarejo, M. (2004). Making a difference for minorities: evaluation of an educational enrichment program. Journal of Research in Science Teaching, 41(9), 861-881.

Bascom-Slack, C. A., Arnold, A. E., \& Strobel, S. A. (2012). Student-directed discovery of the plant microbiome and its products. Science, 338(6106), $485-486$.

Bauer, K. W. \& Bennett, J. S. (2003). Alumni perceptions used to assess undergraduate research experience. The Journal of Higher Education, 74(2), 210-230.

Boyce, G., Williams, S., Kelly, A., \& Yee, H. (2001). Fostering deep and elaborative learning and generic (soft) skill development: the strategic use of case studies in accounting education. Accounting education, 10(1), 37-60.

Brownell, S. E., Hekmat-Scafe, D. S., Singla, V., Chandler-Seawell, P., Conklin Imam, J. F., Eddy, S. L., -. Cyert, M. S. (2015). A high-enrollment course-based undergraduate research experience improves student conceptions of scientific thinking and ability to interpret data. CBE -Life Sciences Education, 14(2), 1-14.

Brownell, S. E., Kloser, M. J., Fukami, T., \& Shavelson, R. (2012). Undergraduate biology lab courses: Comparing the impact of traditionally based "cook- book" and authentic research-based courses on student lab experiences. Journal of College Science Teaching, 41(4), 36 - 45.

Brownell, S. E., Wenderoth, M. P., Theobald, R., Okoroafor, N., Koval, M., Freeman, S., ․ Crowe, A. J. (2013). How students think about experimental design: Novel conceptions revealed by in-class activities. BioScience, 64(2), 125-137.

Chieffo, L. \& Griffiths, L. (2004). Large-scale assessment of student attitudes after a short-

term study abroad program. Frontiers: The Interdisciplinary Journal of Study Abroad, 10(1), 165-177.

Coker, J. S., Heiser, E., \& Taylor, L. (2018). Student outcomes associated with short-term and semester 
study abroad programs. Frontiers: The Interdisciplinary Journal of Study Abroad, 30(2), 92-105.

Cresswell, J.W. (1997). Qualitative Inquiry and Research Design. Choosing Among Five Traditions. Thousand Oaks, CA: Sage.

Dasgupta, A. P., Anderson, T. R., \& Pelaez, N. (2014). Development and validation of a rubric for diagnosing students' experimental design knowledge and difficulties. CBE-Life Sciences Education, 13(2), 265-284.

Deane, T., Nomme, K., Jeffery, E., Pollock, C., \& Birol, G. (2014). Development of the Biological Experimental Design Concept Inventory (BEDCI). CBE-Life Sciences Education, 13(3), 540 - 551.

De la Rosa, C. L. (2014). Cuántas especies hay todavía por descubrir? BIOMA, 15, 19-27.

Dinerstein, E., Olson, D., Joshi, A., Vynne, C., Burgress, N. D., Wikramanayake, E., ․ Saleem, M. (2017). An ecoregion-based approach to protecting half the terrestrial realm. BioScience, 67(6), 534-545.

Donnelly-Smith, L. (2009). Global learning through short-term study abroad. Peer Review, 11(4), 12-15.

Dresner, M., de Rivera, C., Fuccillo, K. K., \& Chang, H. (2013). Improving higher order thinking and knowledge retention in environmental science teaching. BioScience, 64(1), 40-48.

Goedhart, C. M. \& McLaughlin, J. S. (2016). Student scientists: Transforming the undergraduate research laboratory into a research environment. The American Biology Teacher, 78(6), 502-508.

Gormally, C., Brickman, P., \& Lutz, M. (2012). Developing a test of scientific literacy skills (TOSLS): measuring undergraduates' evaluation of scientific information and arguments. CBE-Life Sciences Education, 11(4), 364-377.

Goudsouzian, L. K., McLaughlin, J. S., \& Slee, J. B. Using yeast to make scientists: A six-week self-guided research project for the cell biology classroom. CourseSource, 1-10.

Harrison, M., Dunbar, D., Ratmansky, L., Boyd, K., \& Lopatto, D. (2011). Classroom-based science research at the introductory level: Changes in career choices and attitude. CBE-Life Science Education, 10(3), 279-286.

[IIE] Institute of International Education. (2013). Open doors 2008: International students in the U.S. and study abroad by American students are at all-time high. Washington, DC.

[IIE] Institute of International Education. (2015). Open doors Report on International Educational Exchange. Washington, DC.

Jones, M. T., Barlow, A. E., \& Villarejo, M. (2010). Importance of undergraduate research for minority persistence and achievement in biology. The Journal of Higher Education, 81(1), 82-115.

Joppa, L. N., O’ Conner, B., Visconti, P., Smith, C., Geldmann, J., Hoffmann, M., ․ Burgess, N. D. (2016). Filling in biodiversity threat gaps. Science, 352(6284), 416-418.

Kloser, M. J., Brownell, S. E., Shavelson, R.J., \& Fukami, T. (2013). Effects of a research- based ecology lab course: A study of nonvolunteer achievement, self- confidence, and perception of lab course purpose. Journal of College Science Teaching, 42(2), 90 - 99.

Lincoln, Y.S. \& Guba, E.G. (1985). Naturalistic Inquiry. Beverly Hills, CA: Sage.

Linn, M. C., Palmer, E., Baranger, A., Gerard, E., \& Stone, E. (2015). Undergraduate research experiences: Impacts and opportunities. Science, 347(6222), 1261757.

Lopatto, D. (2017). Adapting to change: Studying undergraduate research in the current education environment. Scholarship and Practice of Undergraduate Research, 1(1), 5-10.

Lopatto, D. (2004). Survey of undergraduate research experiences (SURE): first findings. Cell Biology Education, 3(4), 270-277.

Lopatto, D. \& Tobias, S. (2010). Science in Solution: The Impact of Undergraduate Research on Student Learning. Washington, DC: Council on Undergraduate Research.

Marriam, S. (1988). Case study research in education: A qualitative approach. San Francisco: Jossey-Bass.

McKeown, J. S. (2009). The first time effect: The impact of study abroad on college student intellectual development. Albany, NY: State University of New York Press.

McLaughlin, J. S. \& Coyle, M. S. (2016). Increasing authenticity and inquiry in the cell and molecular biology laboratory. The American Biology Teacher, 78(6), 492-500.

McLaughlin, J. S., Favre, D. E., Weinstein, S., \& Goedhart, C. M. (2017). The impact of a four-step 
laboratory pedagogical framework on biology students' perceptions of laboratory skills, knowledge and interest in research. Journal of College Science Teaching, 47(1), 83-91.

McLaughlin, J. S. \& Johnson, D. K. (2006). Assessing the field course experiential learning model: Transforming collegiate short-term study abroad experiences into rich learning environments. Frontiers: The Interdisciplinary Journal of Study Abroad, 13(1), 65-85.

McLaughlin, J. S. \& Metz, A. S. (2016). Vision and Change: Why it Matters? The American Biology Teacher, 78(6), 456-462.

McLaughlin, J. S. \& Patel, M. A. (2017). An authentic research experience for undergraduates in the developmental biology and physiology laboratory using the chick embryonic heart. American Biology Teacher, 79(8), 645-653.

Mezirow, J. (2000). Learning as transformation: Critical perspectives on a theory in progress (1st ed.). San Francisco: Jossey-Bass.

Morais, D. \& Ogden, A. (2011). Initial development and validation of the global citizenship scale. Journal of Studies in International Education, 15(5), $445-466$.

[NAS] National Academy of Sciences. (2010). Rising above the gathering storm, revisited: Rapidly approaching Category 5. Washington, DC: National Academies Press.

[NRC] National Research Council. (2000). Inquiry and the national science education standards. Washington, DC: National Academies Press.

[NRC] National Research Council. (2003). BIO2010: Transforming Undergraduate Education for Future Research Biologists. Washington, DC: National Academies Press.

National Survey of Student Engagement. (2007). Experiences that matter: Enhancing student learning and success. Bloomington, IN: Indiana University.

[PCAST] President's Council of Advisors on Science and Technology (2012). Report to the president, engage to excel: Producing one million additional college graduates with degrees in science, technology, engineering, and mathematics. Washington, DC: Executive Office of the President.

Project Kaleidoscope. (2002). Recommendations for action in support of undergraduate science, technology, engineering, and mathematics: Report on reports. Washington, DC: Project Kaleidoscope.

Rhode Ward, J., Clarke, H. D., \& Horton, J. L. (2014). Effects of a research-infused botanical curriculum on undergraduates' content knowledge, STEM competencies, and attitudes toward plant sciences. CBE - Life Sciences Education, 13(1), 387-396.

Russell, S. H., Hancock, M. P., \& McCullough, J. (2007). Benefits of undergraduate research experiences. Science, 316(5824), 548-549.

Schattle, H. (2009). Global citizenship in theory and practice. In R. Lewin (Ed.), The handbook of practice and research in study abroad: Higher education and the quest for global citizenship. London: Routledge.

Schenck, J. \& Cruickshank, J. (2015). Evolving kolb: Experiential education in the age of neuroscience. Journal of Experiential Education, 38(1), 73 - 95

Scott, G. W., Goulder, R., Wheeler, P., Scott, L. J., Tobin, M. L., \& Marsham, S. (2012). The value of fieldwork in life and environmental sciences in the context of higher education: A case study in learning about biodiversity. Journal of Science Education and Technology, 21(1), 11-21.

Seymour, E., Hunter, A-B., Laursen, S. L., \& DeAntoni, T. (2004). Establishing the benefits of research experiences for undergraduates in the sciences: first findings from a three-year study. Science Education, 88(1), 493-534.

Shaffer, C. D., Alvarez, C., Bailey, C., Barnard, D., Bhalla, S., Chandrasekaran, C., ‥ Elgin, S.C. (2010). The Genomics Education Partnership: Successful integration of research into laboratory classes at a diverse group of undergraduate institutions. CBE - Life Sciences Education, 9(1), 55 - 69.

Sirum, K., \& Humburg, J. (2011). The Experimental Design Ability Test (EDAT). Bioscene: Journal of College Biology Teaching, 37(1), 8-16.

Shortlidge, E. E., Bangera, G., \& Brownell, S. E. (2016). Faculty Perspectives on Developing and Teaching Course-Based Undergraduate Research Experiences. BioScience, 66(1), 54-62. 
Spell, R. M., Guinan, J. A., Miller, K. R., \& Beck, C. W. (2014). Redefining authentic research experiences in introductory biology laboratories and barriers to their implementation. CBE-Life Sciences Education, 13(1), 102-110.

Stoner, K. R., Tarrant, M. A., Perry, L., Stoner, L., Wearing, S., \& Lyons, W. (2014). Global citizenship as a learning outcome of educational travel. Journal of Teaching in Travel \& Tourism, 14(2), 149-163.

Tarrant, M. \& Lyons, K. (2012). The effect of short-term educational travel programs on environmental citizenship. Environmental Education Research, 18(3), 403-416.

Tarrant, M. A., Stoner, L., Borrie, W. T., Kyle, G., Moore, R. L., \& Moore, A. (2011). Educational travel and global citizenship. Journal of Leisure Research, 43(3), 403 - 426.

Taylor, E. W. (2001). Transformative learning theory: A neurobiological perspective of the role of emotions and unconscious ways of knowing. International Journal of Lifelong Education, 20(3), 218-236.

Thiry, H. \& Laursen, S. L. The role of student-advisor interactions in apprenticing undergraduate researchers into a scientific community of practice. Journal of Science Education and Technology, 20, 771-778.

Thiry, H., Weston, T. J., Laursen, S. L., \& Hunter, A-B. (2012). The benefits of multi-year research experiences: Differences in novice and experienced students' reported gains from undergraduate research. CBE Life Science Education, 11(3), 260 - 272.

Thomas, C. D., et al. (2004). Extinction risk from climate change. Nature, 427, 145 - 148.

Titeux, N., Henle, K., Mihoub, J., \& Brotons, L. (2016a). Climate change distracts us from other threats to biodiversity." Frontier in Ecology and Environment, 14(6), 291 - 291.

Titeux, N., Henle, K., Mihoub, J., Regos, A., Geijzendorffer, I. R., Cramer, W., Verburg, P. H., \& Brotons, L. (2016b). Biodiversity scenarios neglect future land-use changes. Global Change Biology, 22, $2505-2515$.

Zervanos, S. M. \& McLaughlin, J. S. (2003). Teaching biodiversity and evolution through travel course experiences. The American Biology Teacher, 65(9), 683 - 688. 